Gábor Pusztai

\title{
Pro Cooperatione onderscheiding voor Michiel van Kempen
}

De afdeling Debrecen van de Hongaarse Academie der Wetenschappen reikt elk jaar in februari, tijdens de algemene ledenvergadering de onderscheiding Pro Cooperatione uit. Deze onderscheiding wordt uitgereikt aan personen of aan instituties als blijk van waardering voor langdurig organisatorisch werk en coördinatie op het gebied van internationale samenwerking tussen universiteiten en wetenschappelijke instituten. Nadat Ferenc Postma (Vrije Universiteit Amsterdam) in 2013 en Herbert Van Uffelen (Universiteit Wenen) in 2016 de onderscheiding kregen, werd deze in 2020 weer aan een neerlandicus toegekend. Michiel van Kempen, hoogleraar aan de Universiteit van Amsterdam en lid van de redactieraad van ons tijdschrift, heeft een Pro Cooperatione ereteken mogen ontvangen.

Michiel van Kempen is in 1957 in Oirschot geboren. Zijn middelbare schoolopleiding volgde hij in Eindhoven en later studeerde hij Nederlandse taal- en letterkunde aan de Universiteit Nijmegen. Hij studeerde in 1982 af, promoveerde in 2002 in Amsterdam op Een geschiedenis van de Surinaamse literatuur ( 5 delen; handelseditie in 2 delen bij De Geus, Breda, in 2003). 


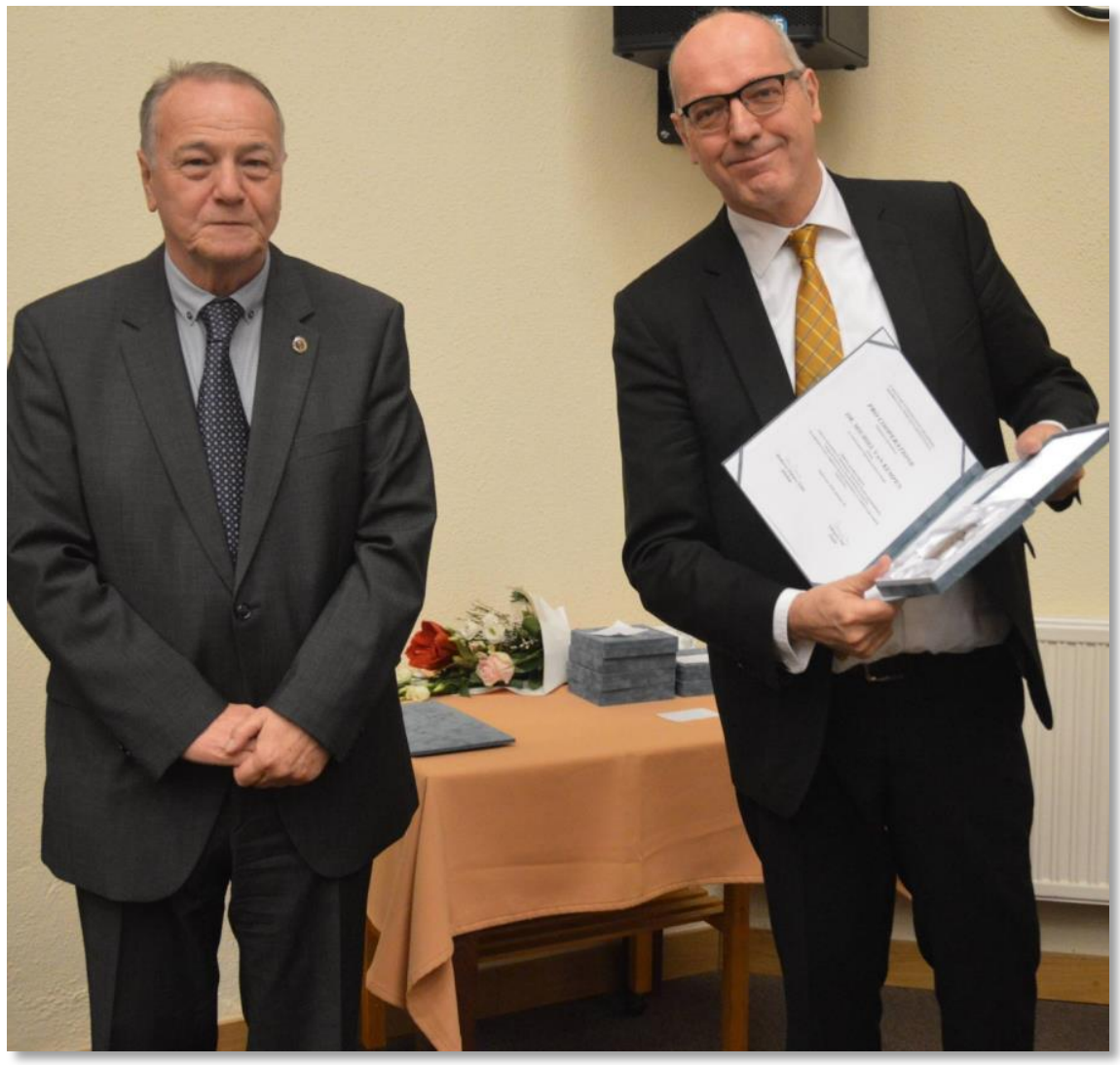

Prof. Dr. Michiel van Kempen neemt zijn onderscheiding in ontvangst. Links staat de voorzitter van de Afdeling Debrecen van de Hongaarse Academie der Wetenschappen, prof. Dr. Pál Gergely.

Aan het begin van zijn loopbaan werkte hij als leraar, journalist, en ook als ambtenaar van een ministerie. Hij woonde jarenlang in Paramaribo, in Suriname. Sinds 1987 geeft hij lessen aan verschillende universiteiten. Sinds 1994 is hij verbonden aan de Universiteit van Amsterdam, waar hij sinds 2006 hoogleraar Nederlands-Caraïbische Letteren is. Hij heeft 47 boeken en meer dan 330 artikelen op zijn naam staan. Zijn inspanningen werden met 7 verschillende onderscheidingen bekroond in binnen- en buitenland. Naast zijn wetenschappelijke loopbaan vervult hij een bijzondere rol als cultuurbemiddelaar. Hij is initiatiefnemer en organisator van verschillende culturele en literaire festivals en congressen. Ook als schrijver van literaire werken is hij belangrijk: hij is auteur van tien romans en verhalenbundels, vier toneelstukken, twee dichtbundels en vier 
filmscenario's. Als literair vertaler heeft hij zeven boeken in het Nederlands vertaald.

Professor Van Kempen is sinds meer dan tien jaar regelmatig gast aan de Vakgroep Nederlands van de Universiteit Debrecen. Hij gaf les aan generaties aankomende Hongaarse neerlandici. Ook op wetenschappelijk gebied is de samenwerking met de Vakgroep Nederlands in Debrecen uitstekend. Wetenschappelijke conferenties, publicaties en projecten geven blijk van intensieve samenwerking. In naam van de redactie en van de Vakgroep Nederlands feliciteren wij professor Van Kempen van harte met deze onderscheiding. 